\title{
Analysis Factors Influencing Use of IUD Contraception on Postpartum Mothers in Dr. Doris Sylvanus Hospital Palangka Raya
}

\author{
Evi Mahlina ${ }^{*}$, Roselina Panghiyangani ${ }^{* *}$, Syamsul Arifin ${ }^{* * *}$, Husaini ${ }^{* * * * *}$, Meitria Syahadatina Noor ${ }^{* * * * *}$ \\ * Central Kalimantan Provincial Health Office, Indonesia \\ ** Department of Biomedicine, Faculty of Medicine, Lambung Mangkurat University, Indonesia \\ ***: Department of Public Health, Faculty of Medicine, Lambung Mangkurat University, Indonesia \\ ***** Master of Public Health, Faculty of Medicine, Lambung Mangkurat University, Indonesia \\ ****** Department of Public Health, Faculty of Medicine, Lambung Mangkurat University, Indonesia
}

DOI: $10.29322 /$ IJSRP.10.08.2020.p104120

http://dx.doi.org/10.29322/IJSRP.10.08.2020.p104120

\begin{abstract}
The use of IUD contraception in postpartum mothers is a safe, effective, and convenient method for women, and is the best opportunity to control postpartum fertility. The use of IUD contraception in postpartum mothers can be influenced by several factors, including education, husband support, information and counseling, and health status. This research aims to analyze the effect of education, husband support, information and counseling, and health status on the use of IUD contraception in postpartum mothers at dr. Doris Sylvanus Hospital Palangkaraya. This is quantitative research with a case-control design. Sample is 158 respondents using purposive sampling method. The research instrument uses secondary data that is registered and medical records. Data analysis is descriptive and analytical, i.e., chi-square and multiple logistic regression. Respondents who have low education will not use IUD contraception ( $\mathrm{p}=0.000$ ). Respondents without husband support will not use IUD contraception $(\mathrm{p}=0.000)$. Respondents who are not provided with information and counseling will not use IUD contraception $(\mathrm{p}=0.000)$. Analysis using multiple logistic regression showed educational variables $(\mathrm{p}=0.001$; Exp. $\mathrm{B}=5.403)$, husband support $(\mathrm{p}=0.000$; Exp. $B=8.675)$, and information and counseling $(\mathrm{p}=0.000$; Exp. $B=7.934$ ) with a confidence level of $95 \%$. There was no influence on the health status of the use of IUD in postpartum mothers. There was an influence of education, husband support, information, and counseling with the use of IUD on postpartum mothers. The husband supports the most dominant of the three variables.
\end{abstract}

Index Terms- education, husband support, information and counseling, health status

\section{INTRODUCTION}

$\mathrm{T}^{\mathrm{s}}$ he postpartum period is an important time to start contraception but is still underused. Many things contribute to unwanted pregnancy, including lack of patient knowledge, ineffective contraceptive methods, inconsistent use of contraception, unplanned sexual activity, and contraceptive failure
(1). Postpartum IUDs are non-hormonal contraceptives that do not have side effects such as hormonal contraception, IUD contraception is safe contraception because in addition to high usability the contraceptive IUD also provides long-term protection for up to 5-10 years (2). Components that influence the behavior of contraceptive use are socio-demographic factors such as age, occupation, number of children, education, and family income. Socio-psychology factors such as men's knowledge about contraception, availability of male contraception, distance to the place of service, information and counseling as well as factors that influence the use of health services such as contraception such as health status, service providers, service acceptance and environmental risk factors (3). Increased morbidity in mothers due to side effects of hormonal contraception, such as hypertension and breast cancer (4). In Indonesia, the number of active family planning acceptors is $63.27 \%$, IUD users only $7.35 \%$ (5). In The Central Kalimantan, postpartum family planning participant as many as $35.3 \%$ of those planning the postpartum least used is the IUD 1.3\% (6). Dr. Doris Sylvanus Hospital shows that from 1635 mothers delivered in the delivery room, only 29 Mothers who use IUD contraception postpartum with a percentage of $1.77 \%$. In 2017, from 1921, there were only 36 women who used postpartum IUD contraception with a percentage of $1.87 \%$. In 2018 out of 1720 women giving birth to only 20 mothers using postpartum IUD contraception with a percentage of $1.16 \%$ (7).

The low coverage of the use of postpartum IUDs is still far from the target of using long-term contraceptive methods (MKJP) in the $2015-2019$ RPJMN is $23.5 \%$ (8). With the above problems, the research will be conducted to analyze factors influencing the use of IUD contraception in postpartum mothers in dr. Doris Sylvanus Hospital Palangka Raya in 2019.

\section{RESEARCH METHOD}

The study begins by determining the case of postpartum mothers who are not acceptors of postpartum IUD contraception and determining the control, namely postpartum mothers who become acceptors of postpartum IUD contraception. Then they are traced retrospectively whether any factors influence it from 
education, husband support, information and counseling, and health status. This study uses secondary data from medical records and registers using checklist sheets as a tool for data collection. The population in this study were all postpartum mothers in dr. Doris Sylvanus Hospital Palangkaraya. The sampling technique in this study was purposive sampling.

\section{FINDINGS}

Table 1. Univariate Analysis of Research Variables

\begin{tabular}{llcccc}
\hline \multicolumn{1}{c}{ Variable } & Category & \multicolumn{5}{c}{ Frequency } \\
\cline { 2 - 6 } & & Case & $\mathbf{\%}$ & Control & \% \\
\hline Education & Low & 37 & 46.8 & 10 & 12.7 \\
\cline { 2 - 6 } & High & 42 & 53.2 & 69 & 87.3 \\
\hline $\begin{array}{l}\text { Husband } \\
\text { support }\end{array}$ & $\begin{array}{l}\text { Not } \\
\text { supported }\end{array}$ & 64 & 81.0 & 20 & 25.3 \\
\cline { 2 - 6 } & Supported & 15 & 19.0 & 59 & 74.7 \\
\hline $\begin{array}{l}\text { Informat i on } \\
\text { and } \\
\text { counse I ing }\end{array}$ & $\begin{array}{l}\text { Non } \\
\text { exposed }\end{array}$ & 45 & 57.0 & 6 & 7.6 \\
\cline { 2 - 6 } Health & Exposed & 34 & 43.0 & 73 & 92.4 \\
status & $\begin{array}{l}\text { No } \\
\text { medical }\end{array}$ & 42 & 53.2 & 44 & 55.7 \\
& indication & & & & \\
\cline { 2 - 6 } & $\begin{array}{l}\text { With } \\
\text { medical } \\
\text { indication }\end{array}$ & 37 & 46.8 & 35 & 44.3 \\
& & & & & \\
\hline
\end{tabular}

Based on the above table, it is known that both in the case group and in the control group the majority of respondents with higher education. There were $53.2 \%$ of respondents in the case group and $87.3 \%$ of respondents in the control group with higher education. The level of education is one of the factors that determine a person's knowledge and perception of the importance of something, including the importance of participation in family planning (9). Higher education levels are able to absorb information and are better able to consider things that are beneficial or side effects to health. The level of education greatly influences a person to act and look for causes and solutions in his life. Educated people will more easily accept new ideas, higher education referred to here is a high school education or equivalent and college (10). In the case group, the majority of respondents did not support her husband while in the control group, majority of respondents there supported her husband. There were $81.0 \%$ of respondents in the case group with no husband support and 74.7 $\%$ of respondents in the control group with no husband support. The husband's support is an encouragement given by the husband in the form of moral and material encouragement in terms of realizing a plan, which in this case is the selection of contraception. Support makes the family able to carry out its functions because family members are supposed to provide mutual support and pay attention to the wife's health conditions and needs. The husband's support is very important for the wife, especially in planning family life as well as in determining the family planning method to be chosen (11).

According to the table above, it is known that both in the case group the majority of respondents did not receive information and counseling were $57.0 \%$ of respondents in the control group were $92.4 \%$ of respondents there is given information and counseling. Counseling is the process of exchanging information and positive interactions about family planning, carried out between prospective family planning participants and staff to help prospective family planning participants recognize their family planning needs and choose the best solution and make decisions in accordance with the conditions faced. Counseling also a process of delivering and receiving messages to improve the knowledge, attitudes and behavior of pregnant women/mothers postpartum/breastfeeding women or mothers after a miscarriage and family/partner, can be done directly/indirectly via a communication channel to receiver message to be able to use contraception directly (12).

It is known that both in the case group and in the control group, the majority of respondents in the use of postpartum IUD contraception with health status had no medical indication. There were $53.2 \%$ of the respondents in the case group, and $55.7 \%$ of respondents in the control group with health status are not medically indicated. Health status can give an idea of a person's physical quality. For example, someone who is sick (infectious or non-infectious, infectious, cardiovascular). Health status is also a state of position of people at a healthy or sick level (13).

Table 2. Bivariate Analysis with Chi-Square Test

\begin{tabular}{|c|c|c|c|c|c|c|}
\hline \multirow{3}{*}{ Variable } & \multicolumn{4}{|c|}{ Postpartum Mother } & \multirow[t]{3}{*}{$\mathrm{p}$-value } & \multirow[t]{3}{*}{ OR } \\
\hline & \multicolumn{2}{|c|}{ No IUD } & \multicolumn{2}{|c|}{ With IUD } & & \\
\hline & $\mathbf{n}$ & $\%$ & $\mathbf{n}$ & $\%$ & & \\
\hline \multicolumn{7}{|l|}{ Education } \\
\hline Low & 37 & 46.8 & 10 & 12.7 & \multirow[t]{2}{*}{0.000} & \multirow[t]{2}{*}{6.079} \\
\hline High & 42 & 53.2 & 69 & 87.3 & & \\
\hline \multicolumn{7}{|c|}{ Husband's support } \\
\hline Not supported & 64 & 81.0 & 20 & 25.3 & \multirow[t]{2}{*}{0.000} & \multirow[t]{2}{*}{12.587} \\
\hline Supported & 15 & 19.0 & 59 & 74.7 & & \\
\hline \multicolumn{7}{|c|}{ Information and counseling } \\
\hline Non exposed & 45 & 57.0 & 6 & 7.6 & \multirow[t]{2}{*}{0.000} & \multirow[t]{2}{*}{16.103} \\
\hline Exposed & 34 & 43.0 & 73 & 92.4 & & \\
\hline \multicolumn{7}{|l|}{ Health status } \\
\hline $\begin{array}{l}\text { No medical } \\
\text { indication }\end{array}$ & 42 & 53.2 & 44 & 55.7 & \multirow[t]{2}{*}{0.873} & \multirow[t]{2}{*}{0.903} \\
\hline $\begin{array}{l}\text { With medical } \\
\text { indication }\end{array}$ & 37 & 46.8 & 35 & 44.3 & & \\
\hline
\end{tabular}

Based on the table above, it can be seen that there are variables that influence the use of IUD contraception in postpartum mothers at dr. Doris Sylvanus Hospital Palangkaraya, namely education ( $\mathrm{p}$-value $=0.000$ ) with an OR value of 6.07, husband's support (pvalue $=0.000$ ) with an OR value of 12.587 and information and counseling ( $p$-value $=0.000$ ) with an OR value of 16.103 . At the same time, the variables that did not affect the use of IUD contraception in postpartum mothers were health status ( $\mathrm{p}$-value $=$ $0.873)$.

Table 3. Multivariate Analysis with Logistic Regression Test

\begin{tabular}{ccccc}
\hline Independent & p- & Exp & \multicolumn{2}{c}{$\mathbf{9 5 \%}$ CI } \\
\cline { 4 - 5 } Variable & value & $(\mathbf{B})$ & Lower & Upper \\
\hline Education & 0.001 & 5.403 & 1.943 & 15.030 \\
\hline
\end{tabular}




\begin{tabular}{lllll}
\hline Husband support & 0.000 & 8.675 & 3.600 & 20.905 \\
\hline $\begin{array}{l}\text { Information and } \\
\text { counseling }\end{array}$ & 0.000 & 7.934 & 2.737 & 23.001 \\
\hline
\end{tabular}

Based on the table above, it can be seen that the most dominant variable influences the use of IUD contraception in postpartum mothers at dr. Doris Sylvanus Hospital Palangkaraya, namely the husband's support (p-value $=0.000)$ with an Exp value $(B)$ of 8.675. Postpartum mothers who do not have the support of their husbands will have a chance of 8.675 times will not use or not become a postpartum IUD acceptor compared to postpartum mothers who have the support of their husbands.

\section{DISCUSSION}

Postpartum IUDs are a safe, effective, and convenient method for most women. For women who lack access to reproductive clinics or health facilities, post- copy IUD is the best opportunity to control postpartum fertility. Other advantages are high motivation to maintain health and help the growth and development of infants and guarantee not to get pregnant again soon (14).

The postpartum period is an important time to start contraception but is still underused. Many things contribute to unwanted pregnancy, including lack of patient knowledge, ineffective contraceptive methods, inconsistent use of contraception, unplanned sexual activity, and contraceptive failure. Of the several factors above that are dependent on individual patients, family planning counseling is a factor that is in the realm of the clinician (1).

Components that influence contraceptive use behavior are socio-demographic factors such as age, occupation, number of children, education and family income. Socio-psychology factors such as men's knowledge about contraception, availability of male contraception, distance to the place of service, information and counseling as well as factors that influence the use of health services such as contraception such as health status, service providers, service acceptance and environmental risk factors (15).

Judging from the characteristics that exist in respoden there are several factors that can affect the use of IUD contraception in postpartum mothers in dr. Doris Sylvanus Hospital Palangkaraya namely education ( $\mathrm{p}$-value $=0.001)$, husband's support ( $\mathrm{p}$ value $=0.000)$ and information and counseling ( $p$-value $=0.000)$. The most dominant factor influencing the use of IUD contraception in postpartum mothers is husband support (pvalue $=0.000$ ) with an $\operatorname{Exp}(\mathrm{B})$ value of 8.675 , meaning that postpartum mothers who do not get husband's support will have 8.675 times greater chance of not using contraception. Postpartum IUDs were compared with postpartum mothers who received husband support. This is in line with the research conducted by Astuti (2019) that the most dominant related variable is the husband's support variable with a p-value of 0.001 with an OR of 19.591 (95\% CI: 3.227 - 118.927). It means mothers who did not get the support of their husbands at risk 19.591 times would not participate as an IUD contraception acceptor postpartum compared to mothers who received husband support.

\section{CONCLUSION}

Based on the results of research and discussion, it can be concluded as follows:

1. There is no influence of health status on the use of IUD contraception in postpartum mothers in dr. Doris Sylvanus Hospital Palangkaraya.

2. There is an influence of education, husband support, and information and counseling on the use of IUD contraception in postpartum mothers at dr. Doris Sylvanus Hospital Palangkaraya.

3. The husband support is the most influences factor on the use of IUD contraception in postpartum mothers in dr. Doris Sylvanus Hospital Palangkaraya.

\section{REFERENCES}

1. Kurniawan, K., \& Siswosudarmo, R. (2019) Effects of Antenatal Counseling on Post-Partum IUD Acceptance Levels. Faculty of Medicine, Public Health and Nursing, Gadjah Mada University. Journal of Reproductive Health. 6 (1); 13-17.

2. Susanti, L., Muhammad, D, .Satriyanto. (2018) Effects of Hormonal Contraception on Blood Pressure. Faculty of Medicine and Health Sciences, Abdurrab University. Pekanbaru. Riau Collaborative Medical Journal . 1 (3); 1-9.

3. Marlina, LS. (2018). Factors That Influence Family Planning Acceptors in the Use of Contraceptive Devices in the Uterus (IUD) in Tegal Sari III Health Center Medan, North Sumatra. Thesis. Faculty of Public Health. The University of North Sumatra.

4. Wahyuni, S. (2015) Risk Factors for Hormonal Contraception Acceptors Against Breast Cancer Incidence in RSUP Dr. Soeradji Tirtonegoro. Journal of Midwifery Involution. 5 (10); 2-11

5. Ministry of Health RI (2018) Indonesian Health Profile. Ministry of Health of the Republic of Indonesia. Jakarta.

6. Central Kalimantan Health Office. (2018) Health Profile of Central Kalimantan Province . Central Kalimantan Provincial Health Office. Palangka Raya.

7. Hospital Dr. Doris Sylvanus Palangkaraya. (2018) Register for Reproductive Health Installation room. Dr. Doris Sylvanus Palangkaraya.

8. RPJMN. (2014) National Medium-Term Development Plan 2015-2019. Ministry of National Development Planning.

9. Indahwati, L., Wati, LR, \& Wulandari, DT (2017). Age and Family Planning Experience Related to the Selection of Contraception Methods, Faculty of Medicine, Universitas Brawijaya. Journal of Issues in Midwifery, 1 (2); 9-18.

10. Sari, T., \& Yulnefia. (2019) Relationship between Demographic Factors and the Use of Contraception in the Womb in Fertile Age Women at Payung Sekaki Health Center, Pekanbaru City. Collaborative Medical Journal . 2 (1); 36-43.

11. Mariati, T. (2018). Husband's Support by Choosing the Use of IntraUterine Device (IUD) in Plumbon Hamlet, Banguntapan Village, Banguntapan District, Bantul, Yogyakarta. Journal of Health Management Dr. Soetomo Hospital Foundation. 4 (2); 98-109.

12. BKKBN. (2017) Regulation of the Head of the National Population and Family Planning Agency Number 24 of 2017. Concerning Post-partum Family Planning and Post-Miscarriage. Directorate of Reproductive Health. Jakarta.

13. Hartanto, H., (2015). Family Planning \& Contraception. Sinar Harapan library. Jakarta.

14. Prawirohardjo, S. (2018) Obstetrics. Build library. Jakarta.

15. Magfirah, N. (2017) Factors Related to the Utilization of Childbirth Services by Antenatal Care Patients at Taman Puring Muhammadiyah Hospital. Thesis. Faculty of Medicine and State Islamic Health Sciences. Jakarta. 


\section{AUTHORS}

First Author - Evi Mahlina, Central Kalimantan Provincial Health Office, Indonesia.

Second Author - Roselina Panghiyangani, Department of Biomedicine, Faculty of Medicine, Lambung Mangkurat University, Indonesia.

Third Author - Syamsul Arifin, Department of Public Health, Faculty of Medicine, Lambung Mangkurat University, Indonesia.
Fourth Author - Husaini, Master of Public Health, Faculty of Medicine, Lambung Mangkurat University, Indonesia.

Fifth Author - Meitria Syahadatina Noor, Department of Public Health, Faculty of Medicine, Lambung Mangkurat University, Indonesia.

Correspondence Author - Evi Mahlina, Central Kalimantan Provincial Health Office, Indonesia, email: evimahlina@gmail.com 